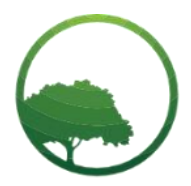

Research in Business \& Social Science

IJRBS VOL 10 NO 3 ISSN: 2147-4478

\title{
Revealing the assets accountability of the Ternate's Sultanate in the era of Sultan Mudaffar Sjah II (1975-2015)
}

\author{
(D) Muhamad Dhanutirto F. Tuwow ${ }^{(a)^{*}}$, (D) Bambang Hariadi ${ }^{(b)}$, (D) Ali Djamhuri ${ }^{(c)}$ Crossref $^{(1)}$ \\ ${ }^{(a, b, c)}$ Department of Accounting, Faculty of Economics and Business, University of Brawijaya Jl. MT. Haryono No.165, Malang, Indonesia
}

\author{
ARTICLE INFO \\ Article history: \\ Received 06 April 2021 \\ Received in rev. form 22 April 2021 \\ Accepted 125 April 2021 \\ Keywords: \\ Asset Accountability, Sultan Mudaffar \\ Sjah II, Ternate's Sultanate, Jou Se \\ Ngofangare. \\ JEL Classification: \\ O15, P36
}

\begin{abstract}
A B S T R A C T
This study aims to construct the assets accountability of the Sultan Mudaffar Sjah II era of the Ternate's Sultanate (1975-2015). The focus of the study was to uncover various forms of embodiment and values contained in accountability during the Sultan Mudaffar Sjah II Ternate's Sultanate. This research uses ethnographic methods developed by River and Boas. The analysis used to answer research questions uses Foucoult's historical thought analysis of Power-Knowledge. Questions were given to several informants who explained that they were competent to support this research. In carrying out asset accountability, the values inherent in the Accountability of Sultan Mudaffar Sjah are based on the philosophy of Jou se Ngofangare which is closely held by the Ternate's Sultanate. Accountability of Jou se Ngofangare is what gave birth to a trilogy of dimensions that instills the values of a harmonious relationship between humans and God, humans and humans, and the relationship between humans and nature. The construction of accountability for Sultan Mudaffar's assets takes several forms: His view is that all property is intended for the people. Much has been done by Sultan Mudaffar Sjah during his leadership in the contemporary era, from protecting all forms of the Sultanate's assets. Starting from accountability for power, accountability for trust and responsibility for customary land, until he also donated land for the public interest in this case to the City Government of Ternate, namely for the construction of Khairun University as well as the construction of an airport.
\end{abstract}

\section{Introduction}

American Accounting Association, (1966:1) define accounting:

"[As] the process of identifying, measuring, and communicating economic information to permit informed judgments and decisions by users of the information" (American Accounting Association, 1966:1)

The definition of accounting above proposed by the American Accounting Association shows that the American Accounting Association places greater emphasis on aspects that have become mainstream, namely technical aspects of accounting. Imanuel (2014) with reference to Suwardjono (2005: 1) explains that accounting practice in an area does not just happen, but has been designed deliberately to achieve its social goals. Therefore, accounting is a scientific discipline that is formed through social activities that occur in society. As a social science discipline, accounting plays a role in the context of culture, law, economy, and socio-politics in society, thus making accounting useful both practically and socially. Sukoharsono \& Qudsi (2008) state that the role of accounting is not limited to fulfilling technical aspects, but also has a social role, namely when accounting is used as a tool of accountability.

The discourse of thinking and reviewing accounting began to develop from various sides such as accounting associated with religion and auditing initiated by Abdel Karim (1990), accounting associated with the social and religious fields by Askary \& Jackling (2004), then also social accounting among maori tribes by Hooper \& Kearins (2008) and accounting disabilities by Bishop \& Boden (2008). All of this explains that the study of accounting is not limited only in the economic aspect, but also in the socio-community aspect. So, accounting is not born only for business records, but is also related to decision-making issues that produce policies in the socialsocial field.

* Corresponding author. ORCID ID: 0000-0001-8511-7803

(C) 2021 by the authors. Hosting by SSBFNET. Peer review under responsibility of Center for Strategic Studies in Business and Finance. https://doi.org/10.20525/ijrbs.v10i3.1149 
When talking about the time dimension, Sukoharsono (2005) says that accounting has three dimensions of time, a past or past dimension called accounting history, the present dimension is the dimension when accounting is used today, while the future dimension is called accounting prediction. Therefore accounting can be present in various social dimensions throughout time and space, even everything has been going on from the past to the present to the future.

The development of accounting up to those used today cannot be separated from past accounting. In ancient times, accounting did not only play a technical role, but also as a controlling creator in the community system. Referring to the thoughts of Sukoharsono (1998) accounting does not have a single aspect alone, but also includes many other aspects of people's lives. As a form of human thought, accounting must continue to be further explored and developed along with shifting thoughts and culture in society (Triyuwono et al., 2016:97). Therefore, studying historical accounting can produce a comparison of current accounting practices through the use of past accounting practice methods (Belkaoui, 2011). However, accountants have been bound by historical accounting, both in the past, present, and future as a continuous process (Triyuwono et al., 2016:82).

Foucault gave the understanding that in understanding contemporary history, we must know the reality that happened and understand how current power takes place (Kamahi, 2017). According to Foucault, there is a close relationship between history, power and science. Therefore, the history of the past will only be understood if we are able to find cracks in an era so that we can also find out what episteme was in power at that time, and how that power operates (geneology of powerI) today. This statement means that Foucault's view is productive and reproductive, that science and history are conceptualized as governmentality.

Stewart (2007) sees Foucault's view of the history and thought of accounting theory as very interesting in relation to the concepts it provides, particularly to challenge mainstream accounting theory. Foucault provides a theoretical framework as a resistance to breaking away from the narrow understanding of accounting theory itself. Accounting was born not from the capitalist process or in the development of the industrial era. Accounting is also not an outcome of investors and part of the organizational structure. Accounting arises from a complex social phenomenon, the result of various interactions that occur (Stewart, 2007). The episteme concept in epoch provides a way to analyze the existence of an accounting episteme in the framework of the kingdom in the past. Several studies in the field of accounting history have used Foucoult's perspective such as the work of Tyson (1993) dan Hoskin (1994).

Along with the development of thinking and the role of accounting that is not fixed on recording alone, as previously explained, there is basically a broader space in defining accounting. Currently accounting is used as a tool to state accountability. Accountability by definition is a manifestation of the obligation to be responsible for the success or failure of the organization's mission in achieving the goals and objectives that have been set through accountability media which is carried out periodically (Sedarmayanti, 2003). Accounting has dived into the realm of accountability and is used as one of the tools that can prove that accountability is successful or not.

Accountability is a method of accountability for management or the recipient of the mandate to the trustee for the management of the resources entrusted to him, both vertically and horizontally. In the traditional definition, accountability is a general term to explain that an organization or company has fulfilled the mission they carry (Benveniste (1991) as quoted by Arifiyadi, (2008:1)). Another definition states that accountability is defined as the obligations of individuals or authorities entrusted with managing public resources and those concerned with them to be able to answer matters concerning their accountability. Accountability is closely related to instruments for control activities, especially in terms of achieving results in public services and conveying them transparently to the public (Arifiyadi, 2008:1)

Accountability is also implied in the Al-Qur'an Surah Al Baqarah 282, which requires recording of every transaction activity. The recording of this transaction will provide information and accountability (the power to be held accountable) for the real conditions that exist to the public as an object, parties who also have the right to question it (Adlan, 2010:1).

This research will try to explore the accountability of assets in the Sultanate of Ternate in the era of Sultan Mudaffar Sjah II. Asset accountability will be interpreted as accounting thoughts whose output produces policies in decision-making and practices related to asset management and accountability. Accountability for the use of assets referred to in this research is accountability for the use of tangible and intangible assets.

The color of accounting in a social system of society that exists and lives in a Sultanate system such as the Sultanate of Ternate is interesting to study as a locus or setting of asset accountability. Because accounting has an important role related to the social life of society, it can be assumed that accounting has played an important role in the management system of the Sultanate of Ternate. All of this is based on the statements of Sultan Mudaffar Sjah II as the 48th Sultan of Ternate which was immortalized in a video related to asset management. In addition, the existence of asset accounting in the Sultanate is also related to ancient relics which may explain the Sultanate's assets which are still neatly stored in a museum in the Sultanate of Ternate. The presumption of this relationship is supported by the statement of Otley \& Berry (1980) which states firmly that accounting can be present at any time. This statement means that the existence of accounting exists in every space and time.

Sultan Mudaffar Sjah II is a figure who always inspires many people, especially the people of Ternate city. The 48th Sultan in the Sultanate of Ternate, left a lot of memories in tradition, culture, and intellectual journey in terms of shari'a and nature which until now continues to be carried out by the kingdom of the Sultanate of Ternate, with the aim of carrying out the "orders" of the sultanate 
in accordance with customs, traditions. and culture that has been instilled from the past to the present. In terms of being a leader of the Sultanate, he has a very extraordinary way of harmonizing the life of the state in the context of the Indonesian state law system and the customary law system of the Sultanate of Ternate, so that it can be used as an example for every Ternate community and the world.

This study refers to Mulya's (2014) research on the Accounting for Assets of the Sultan Syarif Kasim II Kingdom of Siak Sri Indrapura Riau (1908-1946). This study found that the form of the Sultan's responsibility for royal assets was intended as a learning platform to provide education to his people. This explains that Sultan Syarif Kasim used royal assets for the people as a form of accountability.

The color of accounting in a society is formed by a system, it can be a country or another system led by a president or a Sultan. The Sultanate of Ternate is one of the kingdoms that has its own color of accounting, as an Islamic empire with a long history, the Sultanate of Ternate has an accounting system that is thick with the philosophy of life of the Ternate people, namely Jou se ngofangare which has a very deep philosophical meaning. The verse means the relationship between man and God, man and man, also man and nature. This is also held by the Sultan, where every thing that is taken has an accountability to God, Allah SWT. As a divine concept, Jou se ngofangare has a derivative which is the basic law of the Ternate people, namely 1) adat se atorang; 2) Istiadat se Kabasarang; 3) Galib se Lukudi; 4) Sere se Doniru; and 5) Cing se Cingare.

This historical phenomenon is what motivates the desire to examine more deeply the accountability of assets in the Ternate's Sultanate, in order to give the meaning of an accounting thought that can become a system or culture practiced by an organized society or what is called institutional logic. From the above analysis, the author wants to see how the accountability of the assets of Sultan Muddafar Sjah II of the Ternate's Sultanate for the assets of the Sultanate.

\section{Literature Review}

\section{Qualitative Approaches to Revealing Social Reality}

The special character of qualitative research is that it seeks to reveal the uniqueness of certain individuals, groups, communities and organizations in everyday life. Kirk \& Miller (1986) defines qualitative research as a particular tradition in the social sciences which fundamentally relies on observations with human objects. Qualitative research, as expressed by Creswell, (2010:4), is methods to explore and understand the meaning that some individuals or groups of people perceive as coming from social or humanitarian problems.

Noor (2009:32) says that qualitative research is a process of research and understanding based on a methodology that investigates social phenomena and human problems, emphasizes the social nature of reality, the close relationship between the researcher and the subject under study. Furthermore Noor (2009) explains that qualitative research is used when the problem is not clear, knows hidden meanings, understands social interactions, develops theories, ensures data accuracy, and examines the history of development. This qualitative research process involves important efforts, such as asking questions and procedures, gathering specific data from participants, and inductively analyzing data ranging from specific themes to general themes, and interpreting the meaning of the data.

Then Chariri (2009) explains that there are two main reasons that a qualitative approach is needed by economics, management and accounting studies; First, the field of study is not a "value-free" discipline, but on the contrary it is highly dependent on certain values, norms, culture and behavior that occur in a certain business environment. The use of certain numbers (quantification) to reflect behavior, values and other phenomena is not the right solution because it can be misleading and does not describe the real conditions. Then second, not everything related to values, behavior or interactions between actors and their environment can be quantified.

Based on the formulation of the problems previously described, the use of qualitative methods is the choice of researchers to answer this research question. This approach is useful for seeing the social conditions between human behavior and their social environment in more depth. In addition, accounting practice is an activity that is formed in a social order that prevails in society so that it requires deep understanding and meaning that may be reached with a qualitative approach. In this context, a qualitative approach tries to find and reveal the meaning of assets in the view of Sultan Mudaffar Sjah II of the Sultanate of Ternate in managing his assets.

\section{Ethnography as a Methodology}

This study uses ethnography as a research methodology. Ethnography is an option compared to other schools such as ethnometodology or phenomenology because it fits the purpose of this study, which is to explore deeply the Sultan's thoughts in understanding wealth as well as the implications of his accounting policies. Phenomenology as according to Creswell (2010) is used for research with the aim of exploring an object by making subject awareness the most important basis for getting to know the object more deeply. Meanwhile, ethnometodology as expressed by Djamhuri (2011) is a sociological study that seeks to gain an understanding of how certain cultural groups use their cultural elements in their lives.

Ethnography is a research that describes a culture as it is by studying cultural events that present the subject's view of life as an object of study (Endraswara, 2012:50). Ethnography as a social science makes its methodology seen from a naturalist point of view. Naturalism proposes that as much as possible the social world should be explored in a natural setting without the intervention of researchers (Hammersley \& Atkinson, 2007:7). Naturalism is an orientation concerned with the study of social life in real and natural settings; who experience, observe, describe, understand and analyze the features of social life in concrete situations (Brewer, 2000). 
Kamayanti (2016:105) emphasizes that the purpose of ethnography is not only to understand culture but also to find cultural themes that previously did not exist or were not known to exist. Ethnographic research is used to explore and also describe the life of accounting in the midst of social interactions.

The introduction to the book ethnography by Spradley (1997) describes that the early researchers who used ethnography in the world of anthropology were WHR Rivers and Franz Boas. The ethnographic characteristics of Rivers Boas style, get a picture of a society about the "comfortable" life in the past.

River Boas style ethnography is very appropriate to be used in this study, which explores various related literature and confirms it to informants who have past knowledge. In short, this early type of ethnographic research was informant oriented, because the aim was to get a picture of the past of a particular group or society.

\section{Method of Analysis: Foucauldian "Power - Knowledge"}

Foucault's method of historical analysis is power - knowledge, power is a form of geneology, and knowledge is a form of archeology. The first stage of Foucault's thought is geneology, which further develops the history of accounting for the emergence of human science and is directly directed at a way to complete historical analysis of his system of thought. Geneology tells more about the historical process of accounting itself. Foucoult's genology is based on the perspective of historical analysis according to Nietszche, which is intended to identify ruptures of knowledge accidents. Foucoult's geneology is not intended to see the relationship between the present which is influenced by the past, but rather a knowledge that is pure at a time and is discursive (Stewart, 2007). Thus, the position of this research, although it examines the study of the past, is not intended to relate it to the present or in other words the present condition is determined by past conditions, except as a reflection for the present and the future.

The second stage is archeology, which examines the conditions which made possible the emergence of the modern humanities, with a focus on the historical conditions that existed at that time. Archeology tells the story of the historical conditions of accounting at that time. Archeology is defined as an effort to test or analyze archives which are a collection of statements called discourse (Stewart, 2007). This collection of statements is called a discourse or system of thought which is often called an episteme. The episteme is the product of Foucoult's archaeological historical analysis. The episteme in this research is knowledge which is the main objective to be found in producing a concept that has existed for a long time in a certain period.

The source analysis stage was carried out using the Foucault archaeological method, namely through the "Archive" (document) test. Archaeological activity in examining documents consists of first, determining and defining the discourse itself, in this case asset accountability. Second, how to define and define discourse with all its specifications, such as the attitude and actions of Sultan Mudaffar Sjah II towards property. Third, determine the rules for discursive practices, namely those that are only related to accounting. Fourth, rewriting in the form of exteriority in an endeavored form to remain durable, that is, part of the researcher's interpretive.

\section{Data Collection}

Before going any further, the researcher conducted an initial study at the research site, digging up preliminary information and receiving various suggestions to get the right informants. This initial stage is carried out to explore whether the researcher can conduct research or not. This initial stage was carried out on the sidelines of college holidays after Eid al-Fitr 2019, the results were quite satisfying, the researchers got initial information which became the foundation for researchers to conduct research. After completing the proposal exam in December 2019, the researcher asked for a research permit to take to the field to the Ternate Sultanate Kedaton which still stands majestically to this day.

After arriving at the research location, the researcher found various information and data from the 6 informants whom the researcher met. Actually there were 8 informants who were confirmed during the initial study, but the other 2 were unable to because they were not domiciled in that location. Recordings and photos with several informants are listed in a special file and report. After ascertaining the number of informants and the willingness of the research sites, the next step is to collect data using a trasir system.

The search was started by tracing the Kedaton of the Sultanate of Ternate. The search results found various artifacts such as relics and other heirlooms, especially in the physical Kedaton which still stands majestically to this day. Then the researcher made a visit to the Ternate City Library and Archives Office, the researcher found documents such as books related to the history of the Sultanate of Ternate. Then the researchers confirmed and explored the informants. The data collection stage is part of tracing the existing accounting episteme during the era of Sultan Mudaffar Sjah II.

The results of site searches, both documents and artifacts, are historical material which has an objective meaning. Documents and artifacts are historical sources obtained through confirmation and exploration, so they can be analyzed. The analysis is carried out by questioning and exploring historical sources within the framework of criticism of these sources. The results of this analysis can determine the factors as elements of conclusions. At this stage the accounting episteme also exists and finds various ways or knowledge that emerged at that time to solve accounting problems. The conclusion results in the form of determining the factors that are a product of history in a subjective sense. 


\section{Result and Discussion}

\section{Sultan Mudaffar Sjah II and Views About Assets}

Mudaffar Sjah was born in Ternate on April 13, 1938, the 3rd of 4 children of Sultan Iskandar Muhammad Djabir Sjah and Boki Mariyam Cili Gunung Sibela (Daughter of the Bacan Sultanate). Mudaffar Sjah's childhood was passed with tough events. He grew up under the confinement of the Japanese occupation of Ternate, until little Mudaffar and his family had to be evacuated to Brisbane Australia to avoid attempts to exploit and kill the Japanese.

The education given to little Mudaffar was not like the son of the Sultan from other sultans, young Mudaffar was raised outside the palace. Mudaffar did not associate with aristocrats, he grew up in the Dufa-dufa village. This was done by his father so that Mudaffar Sjah could get to know more about Ternate society. This is in line with the philosophy of the Sultanate of Ternate, dadah madopo ${ }^{l}$ (yellow rice and eggs), which is seen by Mudaffar Sjah growing up like children in general, because his childhood lived outside the palace where his father and mother lived.

After the death of Sultan Djabir in 1975 in Jakarta, bobato nyagimoi se-Tufkange $e^{2}$ decided to install Mudaffar Sjah as the 48th Sultan of Ternate. The Jou Khalifah ceremony or the coronation ceremony of the Sultan was witnessed by the palace elite, namely family members, bobato madopolo, to other traditional leaders on November 29, 1976.

The figure of Sultan Mudaffar Sjah became one of the respected figures on the earth of Moloku Kie Raha. He is a very kind and humble figure. As a leader, he never scolded his people and always spoke politely, and had a humorous nature. He always maintains oral speech when issuing opinions or making decisions. He always keeps his heart, words and behavior go hand in hand. As a Sultan, he never differentiates between his people. He is always open to anyone who comes. A figure who has extraordinary charisma, made him chosen by the people of Balakusu Sekano-kano to become Sultan.

As a Sultan who led in the midst of the New Order regime, the Sultan made political decisions to support Suharto's government party, Golkar. The Sultan even appeared and was elected chairman of Golkar in North Maluku Regency at that time. This was solely to survive in the midst of the highly authoritarian and centralized President Soeharto regime.

His views on treasures are interesting to see. He was raised by his father to become a leader who protects the people, making him a leader who has a wise view when talking about wealth. He sticks to what his predecessor taught. He said that all property is reserved for the people.

He never accumulated wealth for himself, but only for the benefit of the people of Ternate and the Indonesian state in general. He thought that this treasure was a mandate that Allah had entrusted for the welfare of His people. This view has shaped him to become a person who is very responsible for the management of the Sultanate's assets.

However, what was touching was that during his leadership he did not feel the welfare of his people. His attitude, coupled with his highly educated background, as well as his dislike of piling up wealth made him a highly respected Sultan and possessed high prestige in the eyes of his people, balakusu se kano-kano. Adhering to Islamic philosophical values is what makes the Sultan very responsible for the Sultanate's assets.

\section{Asset Accountability Practices by Sultan Mudaffar Sjah II: All for the People}

The concept of accountability, which means accountability, is a term related to governance that is actually too broad to define (Mulgan, 2000). Currently, accountability from the side of conventional accounting tends to be profit-oriented, and prioritizes disclosure to shareholders such as investors or capital owners. Conventional accountability tends to override moral values, both in disclosure and behavior. Accountability in its function is not only about reports and disclosures, but also related to human behavior.

Accountability has several forms, namely public accountability which is divided into two, namely vertical accountability and horizontal accountability. Vertical accountability is accountability for fund management to higher authorities, for example the accountability of work units (services) to local governments, regional accountability to the central government, and the central government to the MPR and the most essential vertical accountability is accountability for managing performance assets to God as the highest authority. Horizontal accountability is accountability to the wider community.

In the perspective of the Sultanate of Ternate, the form of responsibility can be seen in the leadership of a Sultan in carrying out the mandate he carries for the benefit of his people, balakusu sekano-kano.

\footnotetext{
${ }^{I}$ In philosophy, dadah Madopo is a mountain-shaped pile of rice and the top is decorated with an egg. Yellow rice is the people, while the egg is the Sultan. The two of them have an inseparable relationship, there is no Sultan without the people, and vice versa. If you open the inside of the egg, the inside is yellow, it means that in the heart of the Sultan there are people.

${ }^{2}$ Bobato nyagimoi se tufkange or Dewan 18, in the structure of the sultanate as the House of Representatives.
} 


\section{Responsibilities of the Sultan: Beyond the Government Contract}

The responsibility of Sultan Mudaffar Sjah as Sultan of Ternate as the 48th Sultan can be seen from the way he manages the assets entrusted to him, the mandate that he carries solely for the benefit of his people, balakusu sekano-kano. He always views property as a deposit from Allah SWT for his people.

The forms of accountability from the Sultan that can be interpreted and practiced by a Sultan are related to the responsibility towards the people.

The responsibility behind the contract when inaugurated is indeed an interesting thing, where the responsibility of the Sultan is not directly contained in the contract. In the contract, there are rights and obligations that bind the Sultan to balakusu sekano-kano. The Sultan is obliged to prosper all his people and protect and protect the rights of his people.

The Sultan also opens himself to be criticized by his people when he makes mistakes or does not keep what has been mandated. This criticism is conveyed through the beauty of movement, namely a dance called the Legu Kadato dance, while dancing behind it is accompanied by rhymes similar to sinden. The verse reads "You sat there because of us, you should never deceive us, wrongdoing $u s "$. This dance has a meaning as a material for reflection on the Sultan, as what has been done for the people of Ternate. This is a reprimand to remind the Sultan of his responsibilities, which is all done with a special customary procession to admonish the Sultan. This dance can only be played at major events, and must be performed in front of the Sultan, even if the President cannot necessarily ask for it.

All of this made the Sultan always try to do everything wholeheartedly to the limit of his ability, and was ready to accept the consequences for his mistakes. Such a contract is very important for a relationship between the people and their leaders who are elected by the people themselves. Because in the contract itself, there is an agreement that is not binding between the people and the Sultan, but goes beyond that, namely the relationship with his Lord, Allah Subhanahu Wa Ta'ala, where rights and obligations are attached to the contract. All will be accountable to God.

Much has been done by Sultan Mudaffar Sjah during his leadership in the contemporary era, starting from safeguarding all forms of the Sultanate's assets. Starting from the accountability of power. The accountability of Sultan Mudaffar Sjah II's power also includes responsibility for inheritance. The classification of the inheritance of the Sultanate of Ternate is divided into three parts, namely oral, written and visual inheritance. Oral inheritance is a legacy in the form of oral literature that lives among the indigenous people of Ternate, which have existed since the birth of the Ternate community itself.

Then the accountability trust, the intangible property of Sultan Mudaffar Sjah II is trust. Trust is a mandate given by the people to the Sultan. Respect and obedience to what the Sultan ordered is a form of moral trust given to him. When the people give power to the Sultan, on the other hand the Sultan manages the mandate given by his people. Thus creating a frequency between the Sultan and balakusu sekano-kano. The people with this resentment obey what the Sultan ordered, and the Sultan is not allowed to do wrong to his people.

The accumulation of intangible assets owned by Sultan Mudaffar Sjah such as power and trust also gave birth to his title as Tubaddilur Rasul or successor to the Prophet. Title makes him a person who is considered to have supernatural powers. Supernatural powers are interpreted as something very unusual. Every word he always believed by his people would bring goodness and provide safety. When he issued Iddin Kolano and Jaib Kolano it became a taboo if anyone broke it. It is even believed that if they violate, that person will go insane.The title owned by Sultan Mudaffar Sjah added charisma in him, even he had a charisma that was inherent in him. The people responded to this view, the high degree on his shoulders and his charisma made the Sultan feared by his people.

The responsibility for customary land in the Sultanate of Ternate, the law that applies to customary land rights is still based on customary law. Land registration in the Sultanate of Ternate is automatically registered in the Sultanate when it is given to someone, but the process does not use a certificate but has an official letter from the Sultanate as a gift from the Sultanate.In the contemporary era of Sultan Mudaffar Sjah II, the Basic Agrarian Law issued by the central government was in effect, but the settlement of the lands of the Sultanate of Ternate by the Government of the Republic of Indonesia could not be carried out. Everything is still valid in customary law, but all granting of customary land rights is converted by the issuance of land certificates by the State through the National Land Agency.

Despite the conversion and issuance of land certificates by the State, the status of the traditional lands of the Sultanate of Ternate is respected and respected. So that on this basis, the granting of land rights in the Sultanate of Ternate still requested permission from Sultan Mudaffar. So that the position as the ruler of land rights is still held by the Sultan.

During his reign, Sultan Mudaffar had provided land grants, namely aha kolano for the benefit of the Ternate City Government, namely land in the form of airport development, Khairun University, schools and so on. This effort was carried out by the Sultan as a responsibility for the mandate given to him and also a form of concern for advancing Ternate in today's contemporary era. Until his return, all of the customary lands had been divided to those who were entitled to receive them.

Construction of Asset Accountability in the era of Sultan Mudaffar Sjah II of the Sultanate of Ternate 
In the form of accountability model shown by Sultan Mudaffar Sjah II, which is embodied in the basic values that are bound in it. These values are the driving factor for the realization of the accountability of the assets of Sultan Mudaffar Sjah II of the Sultanate of Ternate. The basic value in the practice of accountability model Sultan Mudaffar Sjah II treasure can be seen in the figure below:

\section{Accountability Practice Model: Sultan Mudaffar Sjah II in the Framework of Jou Se Ngofangare}

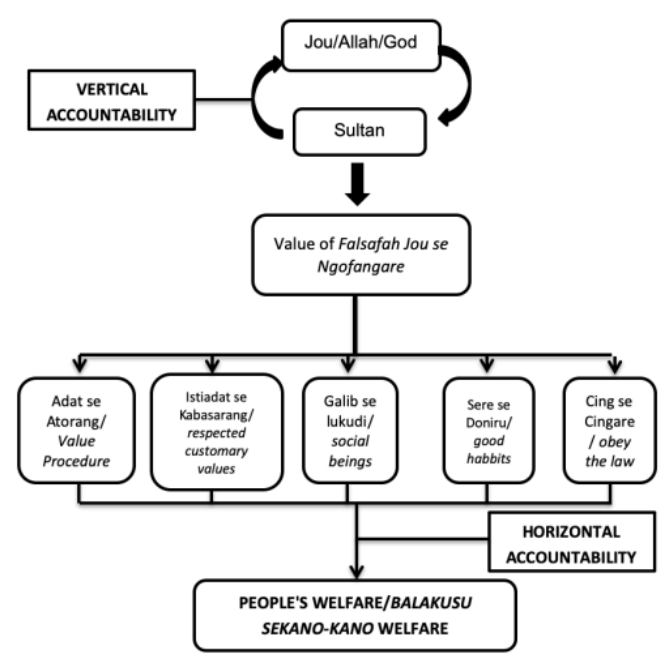

Figure 1: Results of field data processing

From the above model, it can be seen that there is a value attached to the practice of accountability of Sultan Mudaffar Sjah II of the Sultanate of Ternate in the framework of the jou se ngofangare philosophy, among others, as follows: Jou / Allah sends someone as a Khalifah on earth in the form of a Sultan. Sultan who received the mandate from Allah applied the values of the jou se ngofangare philosophy of accountability, which were regulated in the basic state law of the Sultanate of Ternate known as the Five Basic Precepts or Kie se Gam magogugu matiti rara, namely, 1) adat se atorang; 2) Istiadat se Kabasarang; 3) Galib se Lukudi; 4) Sere se Doniru; and 5) Cing se Cingare.

Adat seatorang values are the basic laws derived from the Al Quran and Sunnah. This basic law is a yardstick in the implementation of customs which is used as a guide for the social life of the community. Adat seatorang is a legal product that was previously carried out repeatedly and continuously by the Ternate community as a guarantee of customary law certainty in order to maintain balance and harmony. Adat se atorang a divine law that must be applied by humans. And it has become a stipulation that human behavior is limited by a number of rules so that there is a harmony and balance of the relationship between them.

The attitude of keeping the adat se atorang values in the context of the realization of accountability would be successful if it adhered to the correct actions appropriate customs and rules. Manifestation of the act had an impact on the behavior of the Sultan of understanding of the duties and responsibilities as a human in managing the trust received. Adat se Atorang is the basic principle that shapes asset accountability, which is the main element in establishing openness to disclose information as it is and free of manipulation. So, accountability is closely related to customs and rules which directly raise awareness that it is a mandate from Allah SWT that must be maintained and conveyed to interested parties, in this case the people themselves.

Second, the istiadat se kabasarang values. Istiadat se kabasarang are power rights and rights of Kolano or sultan who have the status of honor, title, crown, palace, and veto rights which are called jaib Kolano. As amir or sultan, the community must respect and obey all the orders that he commands, all orders are carried out on the basis of Islamic truth. Al Quran highly appreciates the existence of a leader, especially a leader who can guide and direct the community to the values of truth. Al Quran says "You obey Allah and His Messenger and you obey your leaders" (Surah an Nisa: 59).

Adat se Kabasarang suggests that a leader must be respected and obeyed because of his justice and wisdom in leading society, they are also responsible for the running of state governance. In the past, the leader or king was considered a drop of the gods, because of that the leader must be firm, have a steel mind and have a strong belief (Agus, 2009:72)

As one of the values that shapes the accountability of assets, adat is one of the Sultan's guidelines in carrying out the mandate. The people will obey the Sultan if the Sultan maintains the trust given by his people. The Sultan's glory and wealth depend on his protection of the people and his appreciation of the people's welfare. Wealth is not just possessions. Wealth depends on the situation, that is, if the people of the country are not divided, there is no dispute. In order to keep the main wealth from being damaged, the Sultan must continue to think about the good and the welfare of the country and its people, the king must carefully consider all his policies and actions.

Third, the value of Galib as Lukudi. The custom of galib se lukudi is the right of origin and human rights, or the right and position of soa or clan according to their origin. Equality in fulfilling one's rights and obligations according to social status, either as a leader, 
apparatus of the Sultanate or the common people. As one of the values that supports the accountability of assets by Sultan Mudaffar Sjah, the fulfillment of community rights and obligations is carried out according to their social status in society. For example, royal officials are given respect by the community based on the soa or clan they carry, as well as other rights such as granting land houses and others by the sultan (Sulaiman, 1995:45).

The custom of galib se lukudi suggests that one's personal rights and the rights of others should be respected and upheld according to their habits. Likewise, the right of cocatu means the right of the sultan to grant land, garden for the private person of a royal official and / or to soa who works in the kingdom. So to support the value of accountability, responsibilty fulfillment of rights and obligations is mandatory in managing the Sultanate's assets which are solely for the welfare of the people.Fourth, sere se doniru values. The value of sere se doniru is an order of cultural and artistic life that arises in community interactions that are mutually accepted. The value of sere se doniru is one of the values to support the accountability of assets of Sultan Mudaffar Sjah, where this value is in the form of good habits and is useful in maintaining harmony in life together, as long as it does not conflict with applicable laws such as: marriage procedures, the procedures for traditional ceremonies and the procedures for social harmony in social life. By maintaining this value, the Sultan has indirectly fulfilled the mandate given to him. Until he passed away, where the Ternate Sultanate had long merged into the Unitary Republic of Indonesia, this value was still held firmly from generation to generation.

Fifth, Cing se cingare values. The value of Cing se cingare often represents discipline and obedience to applicable laws, including discipline and appearance of a person in public whose actions can be seen and noticed by others. If there is an error, it will receive supervision from various parties.

The value of cing se cingare has a broader meaning, not limited to fellow humans, but the supervision of God, Allah SWT of all human movements, whether done in real time or what is done, is confidential. This value is always held by Sultan Mudaffar Sjah II in carrying out the accountability of the sultanate's assets, where his every action is monitored by his people as well as Allah SWT.

These basic values are essentially moral and godly principles. This shows that the political and economic culture in the Sultanate of Ternate is closely related to morality and religiosity. The concept of power is not absolute power. Sultan is the protector of the people. The Sultan is obeyed when he provides protection and shelter to his people, maintains and improves their welfare. The concept of power that is applied is what makes the holder of power as an umbrella, who guides the people to prosperity and maintains the people to obtain their welfare. Power is essentially a mandate and a grace. The power and governance that is administered on the basis of the aforementioned moral and religious values place the adat se atorang, Istiadat se Kabasarang, Galib se Lukudi, Sere se Doniru, and Cing se Cingare.

With regard to accountability, it is interesting to study and explore how the values of the Sultan Mudaffar Sjah II's Accountability value interpret it. (Goodard \& Jackie, 1994) said that the attention of experts today is closely related to the role of accounting to achieve accountability limited to a narrow definition, and rarely consider the impact and issues regarding equity and local wisdom. Evidence that shows the accountability of the assets of Sultan Mudaffar Sjah II using cultural language is reflected in the government recognition that is recognized in the Ternate City Regional Regulation No.13 of 2009 regarding the Sultanate of Ternate.

Furthermore, in carrying out the accountability of the Sultan's assets, he always fences it using cultural values that are closely attached to the Sultanate. These cultural values became the basic law in the Sultanate of Ternate, namely the adat se atorang, Istiadat se Kabasarang, Galib se Lukudi, Sere se Doniru, and Cing se Cingare. This basic law is the content of the divine philosophy of the Sultanate of Ternate, the Jou se Ngofangare Philosophy, which explains the vertical relationship to God and also the vertical relationship to fellow humans as well as the universe. So, it appears that the Sultan does not only carry out the mandate of his people but more than that, to Allah SWT.

From the model of the accountability assets practice of Sultan Mudaffar Sjah II's, it can be seen that it is different from the mainstream system in general. The mainstream approach tends to see accounting and accountability as separate entities from the organizational context, accounting is only seen as a form of reporting objective financial information. This view limits the scope of accounting to the extent of reporting on financial matters, where this can lead to reluctance to use broader information, namely qualitative information that is more subjective in nature. It is this objective view that narrows the definition of accounting and asset accountability.

\section{A View of the Accountability Assets of Tubaddilur Rasul Sultan Mudaffar Sjah II Kesultanan Ternate}

Philosophically, accountability is a mandate. The position of trust is very heavy. Because of the heavy responsibility of carrying out the mandate to humans, the Prophet Muhammad SAW compared trust with faith. As depicted in Ahmad's Hadith below, the Messenger of Allah said:

From Anas bin Malik ra said; The Holy Prophet stated: "It is not someone who believes if he cannot keep the mandate, and someone has no religion if he does not keep a promise" (HR.Ahmad). 
Such is the big responsibility in carrying out the mandate, so a leader must be someone who is trustworthy, otherwise it will undoubtedly bring harm and destruction to something he leads. As described in the Hadith narrated by Bukhari, the Prophet said:

From Abi Hurairah r.a. "If the trust has been wasted, then wait for the time of destruction. "Asked, O Messenger of Allah, how is the waste?" Rasulullah saw. said, "If a task is given to someone who is not an expert, then wait for the time of its destruction." (HR. Bukhari)

Amanah is one that must be developed, when we want to purify our souls and know Allah SWT, because trust is rooted in faith. That is, the nature of trust can be seen from the level of one's faith. The thinner the faith in a person, the less the trust that is attached to him. In line with the hadith of the Prophet SAW "There is no faith for those who do not carry out the mandate", both in the Al-Qur'an and in the Sunnah of the mandate are a requirement for diversity. In human relations between fellow trustees, it is a guarantee that the safety of the relationship is maintained. The safety of a country is guaranteed because the government carries out the political mandate well.

Damage to the mandate will damage the relationship between human beings. The surrender of the mandate to humans by God is intended to elevate the fate of humans to a higher position than the angels as long as the mandate is carried out and will lower them to a position lower than livestock if that trust is neglected.

Amanah is human submission to all the main dimensions of Islam because it involves vertical aspects (hablumminallah), namely the burden of accountability to Allah SWT and horizontal aspects (hablumminannas), namely aspects of sharia, especially in relation to muamalah or human relations with humans in social life.

As Khalifatullah fil Ardh (God's representative on Earth), as described in the Qur'an (QS. Fatir [35]: 39) with a mission as "a blessing for the universe" (Surah Shad [38]: 26) as a mandate from God. Theoretical studies, such as that conducted by Al-Faruqi (1992) say that responsibility is the application of faith (tauhid, belief in the oneness of Allah) for society. According to Al-Faruqi, each individual carries his own burden consciously, the consequence of which is to accept the mandate entrusted by God to everyone.

\section{Tracing the Concept of Asset Accountability}

In terminology, Kholmi (2012) says that accountability comes from the root word "account", which means report. In the Qur'an, the account is hesab (calculation). The word hesab can be seen in the Al-Qur'an, QS Al-Qiyaamah [75]: 14-15, which means: "Even humans bear witness to themselves and even though they state their reasons". If drawn into a general sense, this is related to the obligation of the servant to "account" to Allah SWT in matters relating to human endeavors. The various forms of resources available to humans are the trust of Allah SWT, to be used by humans in order to survive in the world with what Allah has determined, and then they will become provisions in the hereafter.

Accountability literally, in English is called accountability, which is defined as a condition to be accounted for. Or in the adjective it is called accountable, which means responsibility. According to Dubnick (2002), the term accountability comes from the old French "comptes a render" which means to provide a report. Gray \& Bebbington (1998) define accountability as a community right that arises because of the relationship between the organization and society. This definition raises accountability at a broader level that accountability does not only belong to individuals or organizations but belongs to the general public who have closeness or attachment to the individual or organization. Furthermore, Gray \& Bebbington (1998) states that the concept of accountability is within the framework of social responsibility that must be fulfilled as part of the wider community.Ijiri (1983) states that accountability is a commitment of two parties, namely the accountor (maker) and the accountee (receiver). The essential accountability is about providing information between two parties, one party is responsible for providing an explanation or justification to the other party as the responsibility is his right. Two parties in an accountability framework are usually described as principal and agent. Principal is defined as the party who must be held accountable and the agent is meant as the party who is responsible (Gray \& Bebbington, 1998).

At the level of axiology, accountability as a scientific concept requires real practice. To arrive at this level of axiology, accountability is then built within a scientific framework, namely accounting. It was stated by Patton (1992) that accountability is carried out through the reporting function where accounting is the implementation or justification of individual or organizational actions. Accounting then becomes a factual bridge of accountability that can be understood rationally and reliably in order to determine the quality of accountability.

Accounting has a transparent spirit and upholds honesty in every process, from the appearance of an asset to its reporting. Accounting standards provide guidelines for the presentation and disclosure of each item of assets of an entity. Disclosure of assets must meet the requirements of accountability so that the asset report can be communicated with various interested parties. In addition, why an asset accountability report must meet the requirements of accountability, none other than so that the report is truly useful for those who receive the report or have an interest in the report. There are many measures that are used as the basis for fulfilling the requirements to be said to be an accountable report.

Accountability is actually related to the legitimacy of an organization. By legitimacy, it is meant as the status that the organization has, namely that the organization feels that it is trusted to do work or roles based on public recognition. Max Weber explains that power is legitimized by reference to customs and traditions, or to the charismatic claims of personal leaders, or to rational-legal procedures. Traditional legitimacy, namely the belief in a traditional society, that those who according to the old 
tradition hold the government have the right to rule, for example the nobility or the royal family (Weber, 1914).In this connection, (Triyuwono, 2006: 340) sees the concept of accountability in the context of syari'ah accounting, the position of accountability becomes the "soul" or becomes the basis for "ethics" of (on) providing information. Shari'ah accounting is an accountability instrument used by management to God (vertical accountability), stakeholders, and nature (horizontal accountability). If syari'ah accounting is built based on shari'ah ethical values, business practices and accounting carried out by management are also based on shari'ah ethical values, accountability carried out by management is sacred accountability (Triyuwono, 2006: 341). The concept of accountability is closely related to Islamic traditions and understanding of God, humans and the universe (Triyuwono, 1997).

Good accountability can only truly be achieved if accounting and the accountants themselves are bound by a "set of rules" that have more value than just a set of human-created rules. Starting from some of the thoughts and definitions above, it can be used as a basis for constructing jou se ngofangare accountability as a form of accountability with divine values held by Sultan Mudaffar Sjah II.

\section{Accountability of Jou se Ngofangare: Accountability Assets Value of Sultan Mudaffar Sjah II's}

Of all forms of accountability, Sultan Mudaffar Sjah II's assets contain an element of value that is always inherent in it. These values are implied and become an important factor for the realization of the accountability of Sultan Mudaffar Sjah II's assets in the Sultanate of Ternate. The values that underlie the accountability practice of Sultan Mudaffar Sjah II's assets are known as Jou se Ngofangare. The value inherent in the Jou se Ngofangare philosophy is a divine concept that regulates the pattern of human relationships with God, humans and nature, and humans and humans.

Based on the philosophy of Jou se Ngofangare, the life of the Sultan and his people is regulated in a single unit which is inseparable from adat matoto agama, agama matoto kitabullah, kitabullah matoto Jou ta'ala (customs based on religion, religion based on the book of Allah, the book of Allah according to Allah SWT). The philosophy of Jou se Ngofangare is a tauhid teaching that has long been embedded in the Sultanate of Ternate which was believed long before Islam came to Ternate.

The Jou se Ngofangare values held by Sultan Mudaffar Sjah, coupled with the personality that he had Qalbi, Qauli and Fi'li (guarding the heart, speech and behavior) went hand in hand to make him very responsible for the assets entrusted to him, all just for its people. So the form of accountability of Sultan Mudaffar Sjah II which is full of values is different from conventional accountability in general, as illustrated below:

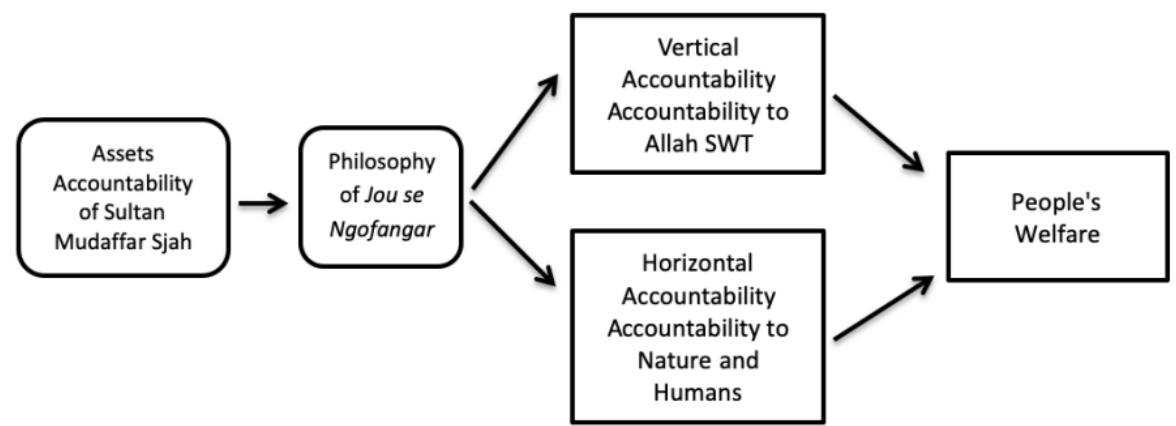

Figure 2: Results of analysis and data processing on Sultan Mudaffar Sjah II's Accountability Model

This is where it is important to describe the form of an accountability concept based on the values of Jou se Ngofangare, namely the dimension of human relations with God and the dimension of human relations with nature which is derived from the philosophy of the trilogy of accountability of Jou se Ngofangare.

\section{Jou se Ngofangare's Accountability Dimension Trilogy}

The philosophy of the Jou se Ngofangare accountability trilogy are three basic things that become pillars to strengthen its existence as a concept of accountability. These three things, namely the giver of the mandate (Allah), the recipient of the mandate (humans), and the mandate itself (the universe). The value inherent in the Jou se Ngofangare philosophy is a divine concept that regulates the pattern of human relationships with God, humans and nature, and humans and humans.

Ontologically, "Jou se Ngofangare" is "al-Awwal" in the sense that it is the initial cause or "article" of everything. If everything was done by Al-Awwal, then it is inevitable, all of nature must have come from Al-Awwal, namely "Jou se Ngofangare". At this stage there was an initial dialogue between "You" and "I", until finally there was ma'rifah. This incident is depicted in the oral literature of Ternate in the form of dolo bololo which has a religious-philosophical meaning "Gudu Moju si to nunako ri Jou Si to Suba" which means: "I already know Him, therefore I worship Him". After Islam entered, Jou se Ngofangare became correlative with two sentences of creed, Asyhadu alla ilaha Illallah is "Jou", and wa asyhadu anna Muhammadarrasulullah is "ngofangare". 
the Sufistic concept, Jou se Ngofangare is understood as the concept of Nur Muhammad, Jou is Allah and Ngofangare is Nur Muhammad. Speaking of the period before the creation of all things, those that existed at that time were Allah and Nur Muhammad. This is a form of depiction of the beginning of creation, that the universe and everything in it, including humans, was created through Nur Muhammad who emanated from Allah SWT. Nur Muhammad has two lines of relationship, namely the relationship with the universe as the principle of the creation of nature, and the relationship with humans as human nature or Insan kamil.

The capacity of Me and Thou is God and Servant, which is an abstract concretization of pure intuition. Thus, Sultan Mudaffar Sjah (2001) said that pure intuition is an a priori condition and forms knowledge abstractly. This knowledge he calls intellectual knowledge because it is able to translate supersensible reality.

Ontologically, the philosophical foundation of Jou se Ngofangare above opens our understanding that the concept of Jou se Ngofangare Accountability to be built reflects the reality of the world and the hereafter which is reflected as godly accountability. Referring to the trilogy philosophy above, this study describes the accountability derived from the relationship between humans and God (Hablumminaallah), and the relationship between humans and humans (hablumminannaas), as well as the relationship between humans and nature (hablum fil ardh). The following will explain the dimensions of this relationship from a human perspective.

\section{Accountability Jou se Ngofangare: Dimensions of Human Relationship with God}

Allah SWT said QS. Al-anbiya ': 107 "Wama Arsalnaka Illa Rahmatan Lil'alamin", which means "And I did not create you (Muhammad), but to be a blessing for the universe". This verse illustrates that humans are creations that are given the trust and mandate of Allah to rule this world. As God's representatives on earth, humans carry a large mandate that is not borne by other God's creatures. Ibn 'Abbas said that Rasulullah saw. ever said (which means):

"Allah said to Adam," O Adam, I have put forth a mandate to heaven and earth, but they are not able to carry it out. Are you able to carry it with what is in it?", Adam asked," What is in it, O my Rabb?", Allah replied," If you carry it then you are rewarded and if you ignore it then you will be punished." Adam then carried it with what was in it. Adam did not live in Heaven except the size between the first prayer to the Asr prayer until the devil took him out of heaven. (HR Tirmidhi).

Based on the description above, as the representative of God on earth, the Khalifah, humans are given a mandate and responsibility. The mandate given to Sultan Mudaffar Sjah for the assets of the Sultanate will be prosecuted before Allah SWT as a form of responsibility for the actions he takes on assets in the hereafter. Ibn Mas'ud said that the mandate includes all human obligations according to their position. The heaviest mandate is the trust of assets. During his leadership, if the mandate he carries is carried out according to His Shari'a by referring to the Al-Qur'an and Sunnah, then he will get happiness in the world and the hereafter (conveying the haq, avoiding the vanity).

From the values contained in the dimension of the human relationship with God, it is found that the concept of transcendent accountability shows the professional and transparent values of a leader. This dimension describes the theological aspects that a person feels as the basis for realizing the value of accountability.

\section{Accountability of Jou se Ngofangare: Dimensions of Human-Human Relationships}

As Allah's creatures, humans are seen as being of the highest rank compared to other Allah's creatures, even Allah ordered the angels to prostrate to Adam Alaihi Salam. Humans have the potential in the form of the ability to think (given reason) and the science of communicating and interacting with the social environment. Kholmi (2012) states that as social beings, humans need interaction and communication to fulfill their nature as social beings. This means that humans are given tasks and responsibilities by Allah SWT between human beings for every aspect of life.

In terms of the accountability of Sultan Mudaffar Sjah II, the implementation of accountability to fellow humans is manifested in the form of respect for the rights of the people and the implementation of obligations for the benefit of the people. In the philosophy of Jou se Ngofangare embodied in government, namely Jou is the leader and Ngofangare is the people, this means that the Sultan is fully responsible for the welfare of his people. Thus, as Allah says in QS Shad: 26, which means:

"O David, we actually made you caliph (ruler) on earth, so give decisions among humans fairly and do not follow lust. Because he will lead you astray from the way of Allah...."

So it can be drawn a common thread that the human dimension with humans has the aim of creating a social order that brings justice, strengthening ukhuwah as well for the sake of broad benefit.

\section{Accountability of Jou se Ngofangare: Dimensions of Human Relations with Nature}

According to Amerieska et al., (2012) Nature and humans are two interdependent things, human life and death cannot be separated from the contribution made by nature, likewise nature without human hands is like a sky without stars. But unfortunately it is humans who tend to underestimate nature, which is undeniable the occurrence of damage, and natural disasters are the act of some people who are not aware that their actions have automatically become bombardments for themselves. For this reason, it is necessary to maintain harmony in reaching natural peace. If this harmony is maintained, the balance of utilization and preservation of nature will have an impact on peace on this earth. 
Allah as the creator of the entire universe is proof of Allah's love for His creatures. The essence of nature is God's creation which must be preserved and developed. Nature is a teacher for humans and a sign of God's power. If we understand the big and small things that exist in nature, nature has many benefits for humans. For example, the wind in the ocean helps fishermen to navigate the oceans, the water in rivers and dams can be used as energy for hydroelectric power. Salle (2015) states that humans are only the holders of the mandate from Allah who only has the right to use, manage and maintain the wealth of the universe according to His law. Those who do not use their property do not have ownership rights. Humans are obliged to manage and maintain this natural wealth as well as possible and are prohibited from doing damage on the earth because this universe belongs to Allah which is intended for all human beings, not individuals.

In terms of the accountability of Sultan Mudaffar Sjah II, the implementation of accountability to nature is always carried out with gratitude, preserving nature and conveying the rights of the people for the management of agricultural products. One thing that has become a tradition that is routinely done is the ritual of kololi kie, fere kie and also praying kie prayers. This is a form of gratitude to Allah SWT for all His bounties, abundant natural wealth.

Thus, as leaders or representatives of God on earth, in this life we must be truly responsible for the preservation of nature, in order to be a form of gratitude for all His gifts.

\section{Conclusions}

This study aims to construct the accountability of assets in the era of Sultan Mudaffar Sjah II, the Sultanate of Ternate (1975-2015). The focus of research is to reveal the various forms of manifestations and values contained in accountability during the Sultan Mudaffar Sjah II era of the Sultanate of Ternate.

Sultan Mudaffar Sjah's accountability construction takes several forms: His view of assets is interesting to see, he thinks that all assets are reserved for the people. This view has shaped him to become a person who is very responsible for the management of the Sultanate's assets. Much has been done by Sultan Mudaffar Sjah during his leadership in the contemporary era, from protecting all forms of the Sultanate's assets. Starting from accountability for power, accountability for trust and responsibility for customary land, until he also donated land for the public interest in this case to the City Government of Ternate, namely for the construction of Khairun University as well as the construction of an airport. As we know, the Sultan still holds the highest position as the ruler of land rights.

In carrying out asset accountability, the values inherent in Sultan Mudaffar Sjah's Accountability are based on the Jou se Ngofangare philosophy which is closely held by the Sultanate of Ternate. The accountability of Jou se Ngofangare is what gave birth to a dimensional trilogy that instills the values of a harmonious relationship between humans and God, humans and humans, as well as human relationships with the natural surroundings.

Jou se Ngofangare's accountability in the dimension of human relations with Allah reveals that as God's representative on earth, the Khalifah, humans are given a mandate and responsibility. The mandate given to Sultan Mudaffar Sjah for the assets of the Sultanate will be prosecuted before Allah SWT as a form of responsibility for the actions he takes on assets in the hereafter. Ibn Mas'ud said that the mandate includes all human obligations according to their position. The heaviest mandate is the trust of assets. During his leadership, if the mandate he carries is carried out according to His Shari'a by referring to the Al-Qur'an and Sunnah, then he will get happiness in the world and the hereafter (conveying the haq, avoiding the vanity). From the values contained in the dimension of the human relationship with God, it is found that the concept of transcendent accountability shows the professional and transparent values of a leader. This dimension describes the theological aspects that a person feels as the basis for realizing the value of accountability.

Jou se Ngofangare's accountability in the human to human dimension, Sultan Mudaffar Sjah II, in the realization of accountability to fellow human beings is manifested in the form of respect for people's rights and the implementation of obligations for the benefit of his people. In the philosophy of Jou se Ngofangare embodied in government, namely Jou is the leader and Ngofangare is the people, this means that the Sultan is fully responsible for the welfare of his people. Thus, as Allah says in QS Shad: 26, which means: "O David, we actually make you a caliph (ruler) on earth, so give judgments among humans fairly and do not follow lust. Because he will lead you astray from the way of Allah.... "Then a red thread can be drawn from the human dimension with humans aiming to create a social order that leads to justice, strengthening ukhuwah also for the sake of broad benefit.

Whereas Jou se Ngofangare's accountability in the human dimension with nature, the implementation of accountability to nature is always done with gratitude, preserving nature and conveying the rights of the people for the management of agricultural products. One thing that has become a routine tradition is the ritual of kololi kie, fere kie and also praying Doa kie. This is a form of gratitude to Allah SWT for all His bounties, abundant natural wealth. Thus, as leaders or representatives of God on earth, in this life we must be truly responsible for the preservation of nature, in order to be a form of gratitude for all His gifts.

These findings show that accounting is not regarded as one of the finished pack, but the form of the social reality where accounting is growing, as in Ternate's Sultanate. It is seen that accounting stands as an institutional logic. 


\section{References}

Abdel Karim, R. A. (1990). The Independence of Religious and External Auditors: The Case of Islamic Banks. In Accounting, Auditing \& Accountability Journal (Vol. 3, Issue 3, pp. 34-44). https://doi.org/10.1108/09513579010004097

Adlan, A. M. (2010). Perbandinan Antara Akuntansi Konvensional dan Akuntansi Syariah. Artikel Keislaman.www.infopesantren.web.id/ppssnh.malang/cgi bin/content.cgi/artikel/index.idx. diakses 5 Oktober 2011.

Agus, B. (2009). Sosiologi Agama 1, Islam dan Pembangunan. Grafindo Persada.

American Accounting Association. (1966). A statement of basic accounting theory. American Accounting Association.

Amerieska, S., Irianto, G., \& Affandy, D. (2012). Akuntabilitas pada Baitul Maal Wat Tamwil Ditinjau dari Perspektif Shari'ate Enterprise Theory. Jurnal Ekonomi Dan Keuangan Islam, 2(1), 27-39.

Any, N. (2009). Management Event. Bandung: Alfabeta.

Arif, I. G. (2017). Kesultanan Ternate Pada Abad XVI-XVII (Kajian Historis Tentang Peranannya Terhadap Perkembangan Islam) (Vol. 4, pp. 9-15). UIN Alauddin.

Arifiyadi, T. (2008). Konsep Tentang Akuntabilitas Dan Implementasinya Di Indonesia. Jakarta: Salemba Empat.

Askary, S., \& Jackling, B. (2004). A Theoretical Framework of Analysis of Accounting Prospensity in Different Religions.

Belkaoui, A. . (2011). Accounting Theory 5th ed. Jakarta: Salemba Empat.

Bishop, M., \& Boden, R. (2008). Disabling accounting. Critical Perspectives on Accounting, 19(1), 1-16. https://doi.org/10.1016/j.cpa.2006.08.005

Brewer, J. . (2000). Ethnography. Buckingham: Open University Press.

Budiasih, I. G. A. N., \& Sukoharsono, E. G. (2012). Accounting Practices and The Use of Money in The Reign of King Udayana in Bali : An Ethnoarcheological Approach. Simposium Nasional Akuntansi XV, Banjarmasin, September, 20-23.

Chariri, A. (2009). Landasan filsafat dan metode penelitian kualitatif. Workshop Metodologi Penelitian Kuantitatif Dan Kualitatif, Laboratorium Pengembangan Akuntansi (LPA), Fakultas Ekonomi Universitas Diponegoro Semarang, 31 Juli - 1 Agustus 2009.

Chua, W. F. (1986). Radical Developments in Accounting Thought. Accounting, the Social and the Political, 61(4), 55-66. https://doi.org/10.1016/b978-008044725-4/50009-6

Creswell, J. W. (2010). Research design pendekatan kualitatif, kuantitatif, dan mixed. Yogyakarta: Pustaka Pelajar.

Djamhuri, A. (2011). Ilmu Pengetahuan Sosial dan Berbagai Paradigma dalam Kajian Akuntansi. Jurnal Akuntansi Multiparadigma, 15(4), 1-26. https://doi.org/10.18202/jamal.2011.04.7115

Dubnick, M. J. (2002). Seeking Salvation for Accountability. Annual Meeting of the American Political Science Association, 1-29.

Endraswara, S. (2012). Filsafat sastra: Hakikat, Metodologi, dan Teori. Yogyakarta: Layar Kata.

Goodard, A., \& Jackie, P. (1994). Accountability and accounting: using naturalistic methodology to enhance organizational controla case study. Accounting, Auditing \& Accountability Journal.

Gray, R., \& Bebbington, J. (1998). Accounting and the soul of sustainability: Hyperreality, transnational corporations and the United Nations. Critical Perspectives on Accounting, 1998(April). http://www3.bus.osaka-cu.ac.jp/apira98/archives/pdfs/24.pdf

Gröjer, J. E., \& Stark, A. (1977). Social accounting: A Swedish attempt. Accounting, Organizations and Society, 2(4), 349-385. https://doi.org/10.1016/0361-3682(77)90024-1

Hammersley, M., \& Atkinson, P. (2007). Ethnography: Principles in Practice, Third Edition. New York: Routledge Taylor \& Francis Group.

Handoko, W. (2017). Ekspansi Kekuasaan Islam Kesultanan Ternate di Pesisir Timur Halmahera Utara. Kapata Arkeologi, 13(1), 95. https://doi.org/10.24832/kapata.v13i1.396

Hooper, K., \& Kearins, K. (2008). The walrus, carpenter and oysters: Liberal reform, hypocrisy and expertocracy in Maori land loss in New Zealand 1885-1911. Critical Perspectives on Accounting, 19(8), 1239-1262. https://doi.org/10.1016/j.cpa.2007.02.004

Hopwood, A. G. (1987). The archeology of accounting systems. Accounting, Organizations and Society, 12(3), $207-234$. https://doi.org/10.1016/0361-3682(87)90038-9

Hoskin, K. (1994). Boxing Clever: For, against and beyond Foucault in the Battle for Accounting Theory. In Critical Perspectives on Accounting (Vol. 5, Issue 1, pp. 57-85). https://doi.org/10.1006/cpac.1994.1004

Ijiri, Y. (1983). On the accountability-based conceptual framework of accounting. In Journal of Accounting and Public Policy (Vol. 2, Issue 2, pp. 75-81). Elsevier. https://doi.org/10.1016/0278-4254(83)90001-7

Imanuel, A. (2014). Akuntansi Pada Masa Keemasan Kerajaan Ayudhya. Brawijaya University.

Jensen, M. C. (1983). Organization Theory Methodology. The Accounting Review, 58(2), 319-339.

Kamahi, U. (2017). Teori Kekuasaan Michel Foucault: Tantangan bagi Sosiologi Politik (Umar Kamahi). Al-Khitabah, 3(3), 117133. http://journal.uin-alauddin.ac.id/index.php/Al-Khitabah/article/view/2926

Kamayanti, A. (2016). Metodologi Penelitian Kualitatif Akuntansi: Pengantar Religiositas Keilmuan (Edisi Revisi). Penerbit Peneleh.

Kholmi, M. (2012). Akuntabilitas dan Pembentukan Perilaku Amanah Dalam Masyarakat Islam. Jurnal Salam Universitas Muhamadiyah Malang, Volume 15, hlm. 63-72.

Kirk, J., \& Miller, M. L. (1986). Reliability and validity in qualitative research (Vol. 1). Sage. 
Mashayekhi, B., \& Mashayekh, S. (2008). Development of accounting in Iran. International Journal of Accounting, 43(1), 66-86. https://doi.org/10.1016/j.intacc.2008.01.004

Mulgan, R. (2000). Accountability: An Ever-Expanding Concept?. Public Administration, Vol. 78 No, 555-573.

Mulya, H. (2014). Akuntansi Harta Era Sultan Syarif Kasim Kerajaan Siak Sri Inderapura Riau (1908-1946). Brawijaya University.

Otley, D. T., \& Berry, A. J. (2019). Control, organisation and accounting. Management Control Theory, 5(2), $101-114$. https://doi.org/10.1007/978-1-4899-7138-8_2

Rusdiyanto, R. (2018). Kesultanan Ternate Dan Tidore. Aqlam: Journal of Islam and Plurality, 3(1). https://doi.org/10.30984/ajip.v3i1.631

Salle, I. Z. (2015). Akuntabilitas Manuntungi: Memaknai Nilai Kalambusang pada Lembaga Amil Zakat Kawasan Adat Ammatoa. Jurnal Akuntansi Multiparadigma, 4. https://doi.org/10.18202/jamal.2015.04.6004

Sedarmayanti. (2003). Sumber Daya Manusia dan Produktivitas Kerja. Ilham Jaya.

Spradley, J. . (1997). Metode Etnogra fi. Terjemahan oleh Misbah Yulfa Elisabeth. Yogyakarta: PT Tiara Wacana Yogya.

Stewart, R. E. (2007). Pluralizing Our Past: Foucault in Accounting History. In Fleischman R (Ed) (Ed.), Accounting History: Vol. Volume III. Sage Publications.

Sukoharsono, Eko G. (1998). Accounting in A Historical Transition: A Shifting Dominant belief from Hindu to Islamic Administration in Indonesia *). 1-24.

Sukoharsono, Eko Ganis. (1995). Accounting, Colonial Capitalists, and Liberal Order : The Case of Accounting History in Indonesia during The Dutch Colonial Period of the Mid-to-end of the 19th century. The International Journal of Accounting and Business Society, 3(1).

Sukoharsono, Eko Ganis. (1998). Accounting in a 'New'History: A Disciplinary Power and Knowledge of Accounting. . The International Journal of Accounting and Business Society, 6(2), 48-79.

Sukoharsono, Eko Ganis. (2005). Power/Knowledge on Accounting Discipline and Practice: The Foucauldian Prespektif. Proceding The First Postgraduate Concortium On Accounting.

Sukoharsono, Eko Ganis, \& Lutifillah, N. Q. (2008). Accounting in the golden age of Singosari kingdom: A Foucauldian perspective. Simposium Nasional Akuntansi XI, 1-21.

Sulaiman, M. N. (1995). Adat Segulaha dalam Perspektif Ajaran Islam (Makalah La). Fakultas Tarbiyah.

Suojanen, W. W. (1954). Accounting Theory and the Large Corporation. Accounting Review, $29(3), 391$. http://www.lib.lsu.edu/apps/onoffcampus.php?url=http://search.ebscohost.com/login.aspx?direct=true \&db=bth\&AN=7110 $323 \&$ site $=$ ehost-live \&scope $=$ site

Thomas, T. (1993). Keeping the Record Straight: Foucauldian Revisionism and Nineteenth Century US Cost Accounting History. In Accounting, Auditing \& Accountability Journal (Vol. 6, Issue 2, pp. 4-16).

Triyuwono, I. (1997). “Akuntansi Syari’ah” dan Koperasi Mencari Bentuk dalam Metafora Amanah. Jurnal Akuntansi Dan Auditing Indonesia, Vol. 1., No. 1: hlm. 1-46.

Triyuwono, I. (2006). Perspektif, metodologi, dan teori akuntansi syariah. PT RajaGrafindo Persada.

Triyuwono, I., Djamhuri, A., Mulawarman, A. D., \& Prawironegoro, D. (2016). Filsafat Ilmu Akuntansi: Berpikir Kontemplatif, Holistik, Intuitif, Imajinatif, Kreatif, Rasional dan Radikal dalam Akuntansi. Jakarta: Mitra Wacana Media.

Weber, M. (1914). Economy and Society: An Outline of Interpretive Sociology (C. Edited by Roth, G. And Wittich (ed.)). University of California Press, Berkeley, Los Angeles.

Publisher's Note: SSBFNET stays neutral with regard to jurisdictional claims in published maps and institutional affiliations.

\section{(a) (1)}

(C) 2021 by the authors. Licensee SSBFNET, Istanbul, Turkey. This article is an open access article distributed under the terms and conditions of the Creative Commons Attribution (CC BY) license (http://creativecommons.org/licenses/by/4.0/).

International Journal of Research in Business and Social Science (2147-4478) by SSBFNET is licensed under a Creative Commons Attribution 4.0 International License. 